\title{
Pengaruh Citra Merek, Kepercayaan, dan Komitmen Terhadap Loyalitas Pelanggan Aplikasi Transportasi Online GOJEK di Kota Malang
}

\author{
M. Afif Fathi Ramadhan \\ Mahasiswa Magister Manajemen Universitas Islam Malang \\ Email : afiffathiramadhan@gmail.com
}

\begin{abstract}
This study aims to determine the effect of brand image on trust, brand image on loyalty, brand image on commitment, trust and commitment to loyalty, and indirect influence of brand image on loyalty mediated trust, and indirect influence of brand image on loyalty mediated commitment. The population in this study is unknown. Sampling in this study using incidental sampling and purposive sampling techniques as many as 96 respondents. The analysis is done using path analysis. The results of this study indicate that brand image has a positive and significant effect on trust, brand image has a positive and significant effect on loyalty, brand image has a positive and significant effect on commitment, trust and commitment has a positive and significant effect on loyalty, there is an indirect effect of brand image on loyalty through trust, there is an indirect influence of brand image on loyalty through commitment.
\end{abstract}

Keywords: Brand Image, Trust, Commitment, Loyalty.

\section{PENDAHULUAN}

Persaingan dalam dunia bisnis yang saat ini semakin ketat dalam persaingan untuk menawarkan produk dan jasa yang disukai oleh konsumen. Kebutuhan konsumen yang semakin beragam membuat perusahaan-perusahaan terutama penyedia jasa harus lebih inovatif dan kreatif juga harus menawarkan jasa yang berkualitas agar konsumen dapat merasakan kenyamanan saat menggunakan jasa tersebut.

Bisnis transportasi online merupakan bisnis jasa berdasarkan asas kepercayaan sehingga masalah kepercayaan pelanggan merupakan faktor yang sangat penting dalam menentukan keberhasilan bisnisnya. Dalam kondisi persaingan yang semakin ketat, setiap perusahaan harus berusaha tidak hanya bertahan hidup, tetapi bahkan perusahaan harus bisa bersaing dan berkembang. Salah satu hal penting yang harus dilakukan perusahaan agar bisa bertahan hidup dan berkembang yaitu dengan mempertahankan pelanggan yang ada. Menurut Kotler dan Keller (2013) pelanggan akan loyal jika kebutuhan pelanggan terpenuhi dan merasa puas.

Memiliki konsumen yang loyal akan memberikan keuntungan terhadap perusahaan. Selain produk tetap bertahan di mata konsumen, perusahaan juga akan tetap dapat bersaing dengan kompetitor di pasar. Menurut Lovelock (2010: 76) loyalitas pelanggan merupakan kesediaan pelanggan untuk menggunakan jasa perusahaan dalam jangka panjang. 
Loyalitas merupakan kesetiaan pelanggan terhadap suatu produk atau merek tertentu. Dalam konteks bisnis, loyalitas merupakan kesediaan pelanggan untuk terus berlangganan pada sebuah perusahaan dalam jangka panjang, dengan membeli dan menggunakan barang dan jasanya secara berulang-ulang dan lebih baik lagi secara ekslusif, dan dengan suka rela merekomendasikan produk perusahaan tersebut kepada temanteman dan rekan-rekannya. Banyak faktor dapat mempengaruhi loyalitas pelanggan terhadap suatu jasa, dimana dalam penelitian ini dianalisis melalui citra merek, kepercayaan dan komitmen. Hal itu sesuai dengan hasil penelitian Lamidi (2007), Widyawati (2008), Shihab dan Sukendar (2009), Dewi, dkk (2012) dan Pramudyo (2012) yang menyatakan bahwa citra merek, kepercayaan dan komitmen merupakan faktor yang dapat mempengaruhi pelanggan.

Menurut Sundjoto dan Hadi, (2012) citra merek menjadi hal yang penting untuk diperhatikan oleh sebuah perusahaan, melalui citra merek yang baik maka akan dapat menimbulkan nilai emosi pada diri konsumen dan akan timbul perasaaan positif pada saat membeli atau menggunakan suatu produk bermerek. Sebaliknya jika suatu produk bermerek memiliki citra yang buruk dimata konsumen, maka kecil kemungkinan konsumen untuk membeli produk bermerek tersebut.

Menurut Kotler (2013), citra merek adalah presepsi konsumen terhadap perusahaan atau produknya. Citra merek tidak dapat ditanamakan dalam pikiran konsumen dalam semalam atau disebarkan melalui media saja. Sebaliknya, citra tersebut harus disampaikan melalui tiap sarana komunikasi yang tersedia dan disebarkan secara terus menerus karena tanpa citra yang kuat sangatlah sulit bagi sebuah perusahaan untuk menarik pelanggan baru dan mempertahankan pelanggan yang sudah ada.

Hubungan antara citra merek dan loyalitas bisa dilihat dari sikap dan persepsi konsumen terhadap merek tertentu. Apabila presepsi atau sikap konsumen baik terhadap merek tertentu akan ada indikasi bahwa konsumen loyal terhadap merek tersebut. Teori penghubung antara citra merek dan loyalitas merek menurut Rangkuti (2008) adalah apabila konsumen beranggapan bahwa merek tertentu secara fisik berbeda dari merek pesaing, citra merek tersebut akan melekat secara terus menerus sehingga dapat membentuk kesetiaan terhadap merek tertentu yang disebut dengan loyalitas merek.

Membangun dan mempertahankan kepercayaan terhadap merek juga tidak kalah penting. Menurut Lau dan Lee (1999) menyatakan bahwa kepercayaan terhadap merek adalah kemauan konsumen mempercayai suatu merek dengan segala resikonya karena adanya harapan yang dijanjikan oleh merek dalam memberikan perasaan yang positif bagi konsumen.

Pelanggan yang mempunyai komitmen terhadap perusahaan juga akan mempunyai perasaan yang positif terhadap perusahaan, serta memperlihatkan adanya keinginan untuk tetap mempertahankan menjadi bagian dalam perusahaan. Komitmen pelanggan penting untuk hubungan jangka panjang menurut Jasfar, (2005: 179) "Komitmen adalah rasa saling 
percaya dan mempercayai di antara pihak-pihak yang menjalin hubungan, baik secara tersirat (implisit) maupun yang tidak tersirat (explisit), bahwa hubungan mereka akan berlangsung terus dan masing-masing menjaga agar janji di antara mereka tetap terpelihara".

Loyalitas seorang pelanggan yang setia didefinisikan sebagai orang yang memegang sikap yang menguntungkan terhadap penyedia layanan seperti merekomendasikan penyedia layanan untuk konsumen lain dan melakukan perilaku pembelian kembali (Dimitriades, 2006, dalam Dagger dan O'Brien, 2010: 1535). Selain itu menurut Sheth dan Mittal (2004:387), loyalitas pelanggan adalah komitmen pelanggan terhadap merek, toko, atau pemasok berdasarkan sikap yang sangat positif dan tercermin dalam pembelian ulang yang konsisten.

Pendapat tersebut diatas sesuai dengan hasil penelitian Sahnaz Ubud dan Suzan Ubud (2016) yaitu loyalitas merek tergantung pada komitmen terhadap suatu merek. Selain itu juga sesuai dengan penelitian Susanti dan Wardana (2017) yang menyatakan citra merek berpengaruh signifikan terhadap loyalitas pelanggan citra merek masih mampu berpengaruh positif dan signifikan terhadap loyalitas pelanggan.

Berbanding terbalik dengan penelitian tersebut, hasil penelitian Maliyah (2015) yaitu tidak terdapat pengaruh antara variabel citra merek terhadap kepercayaan, tidak terdapat pengaruh antara variabel citra merek terhadap komitmen, tidak terdapat pengaruh antara variabel kepercayaan terhadap komitmen, tidak terdapat pengaruh antara variabel kepercayaan terhadap loyalitas, akan tetapi terdapat pengaruh antara variabel komitmen terhadap loyalitas.

Dari perbedaan hasil penelitian diatas menyatakan bahwa tidak selamanya citra merek, kepercayaan, dan komitmen berpengaruh terhadap loyalitas. Maka dari itu peneliti melakukan penelitian ini untuk mengujinya kembali dengan variabel yang sama tetapi dengan subyek penelitian yang berbeda yaitu pada pelanggan ojek online.

Salah satu industri yang memiliki merek yang dikenal luas oleh konsumen saat ini adalah industri penyedia jasa transportasi online. GOJEK, Grab, dan UBER merupakan tiga perusahaan besar yang bergerak di industri transportasi online di Indonesia. Era perkembangan internet di tengah-tengah pertumbuhan penduduk yang begitu pesat, internet sangat dibutuhkan untuk memenuhi kebutuhan masyarakat. Kehadiran jasa transportasi berbasis aplikasi online yang menggunakan internet sangat berpengaruh bagi masyarakat dalam segala aktivitas secara cepat dan efisien.

Berdasarkan ketetapan Pemerintah per 1 Mei 2019 mengenai batas bawah dan atas tarif ojek online. Besaran tarif dibagi berdasarkan tiga zona, yakni zona 1 meliputi: Sumatera, Jawa (selain Jabodetabek), dan Bali; zona 2 meliputi Jabodetabek; zona 3 meliputi: Kalimantan, Sulawesi, Nusa Tenggara, Kepulauan Maluku, dan Papua. Tarif minimal yang digunakan adalah sebesar Rp 7.000,00 sampai dengan Rp 10.000,00 untuk sekali pemakaian. Perhitungan tarif tersebut dirasa oleh Pemerintah telah memasukkan perkiraan daya beli masyarakat. 
Hal ini menimbulkan masalah baru. Hasil survei Research Institute of Socio-Economic Development (RISED) yang berjudul "Persepsi Konsumen terhadap Kenaikan Tarif Ojek Online di Indonesia" dalam beritagar.com, menunjukkan sebesar 75,2 persen responden merasa keberatan atas kenaikan tarif ojek online. Konsumen yang menolak kenaikan tarif tersebut merupakan kelompok masyarakat yang sangat sensitif terhadap kenaikan harga. Mayoritas mereka merupakan masyarakat dengan pendapatan menengah ke bawah.

Berdasarkan alasan diatas, Peneliti memilih judul "Pengaruh Citra Merek, Kepercayaan, dan Komitmen terhadap Loyalitas Pelanggan Aplikasi Transportasi Online GOJEK di Kota Malang".

\section{KAJIAN TEORI Citra Merek}

Membangun citra sebuah merek tidak lain bagaimana melakukan komunikasi yang konstruktif efektif dalam menyampaikan pesan-pesan yang ingin dijadikan sebagai tujuan dari sebuah merek untuk menstimuli persepsi konsumen ke arah yang diinginkan perusahaan (Rizal dan Asnan 2009: 235). Agar bisa dikomunikasikan dengan efektif, sebuah identitas merek harus bisa mengena, mudah diingat, fokus, dan memotivasi (Surrachman 2008: 115).

Dari kedua pendapat diatas dapat disimpulkan bahwa untuk membangun citra pada sebuah merek, perusahaan harus membuat suatu identitas merek yang dapat menyentuh hati para konsumen baik dari sisi kualitas, harga, ataupun simbol. Citra yang positif akan membuat merek lebih mudah tertanam di benak konsumen. Lamb dkk (2001: 424) mengatakan merek membantu konsumen untuk mengenali produk-produk yang akan dibelinya kembali dan menghindari pembelian produk yang tidak mereka inginkan.

\section{Kepercayaan}

Menurut Lau dan Lee dalam Fandy Tjiptono (2009:125) berargumen bahwa faktor trust terhadap sebuah merek merupakan aspek krusial dalam pembentukan loyalitas, karena sebagai kesediaan konsumen untuk mempercayai atau mengandalkan jasa dalam situasi resiko, dikarenakan adanya ekspektasi bahwa jasa yang bersangkutan akan memberikan hasil yang positif.

Sedangkan menurut Robbins (2011:97) "trust sebagai ekspektasi atau pengharapan positif bahwa orang lain tidak akan bertindak secara oportunistik, baik secara kata-kata, tindakan, dan kebijakan".

\section{Komitmen}

Menurut Dweyer et al. (2007) dalam Ramadania (2002:42) dalam pemasaran jasa, komitmen dirumuskan sebagai suatu bentuk perjanjian yang tersurat maupun tersirat untuk melanjutkan hubungan antar dua pihak atau lebih. Menurut Ellena (2011:24) komitmen adalah suatu hubungan yang berharga yang perlu dipertahankan terus, dimana masingmasing pihak bersedia bekerjasama untuk mempertahankan hubungan ini. 
Komitmen pelanggan dapat diartikan sebagai keinginan pelanggan yang berlangsung dalam waktu yang lama untuk mempertahankan hubungan yang bernilai atau menguntungkan dengan pihak perusahaan.

Komitmen adalah orientasi jangka panjang pelanggan terhadap hubungan bisnis. Komitmen. Menurut Colquitt (2009:68) ada 3 (tiga) dimensi dari subvariabel tipe-tipe komitmen yaitu affective commitment (komitmen afektif) continuance commitment (komitmen berkelanjutan), dan normative commitment (komitmen normatif).

\section{Loyalitas}

Hasan (2013: 121) mengatakan "Loyalitas pelanggan merupakan perilaku yang terkait dengan merek sebuah produk, termasuk kemungkinan memperbaharui kontrak merek di masa yang akan datang, berapa kemungkinan pelanggan mengubah dukungannya terhadap merek, berapa kemungkinan keinginan pelanggan untuk meningkatkan citra positif suatu produk ."

Sedangkan menurut Oliver dalam Kotler dan Keller (2009:138) adalah komitmen yang dipegang secara mendalam untuk membeli atau mendukung kembali produk atau jasa yang disukai di masa depan meski pengaruh situasi dan usaha pemasaran berpotensi menyebabkan pelanggan beralih.

\section{Kerangka Konseptual Penelitian}

Model konseptual hubungan antara citra merek pelayanan, kepercayaan, komitmen dan loyalitas disajikan dalam Gambar 1.

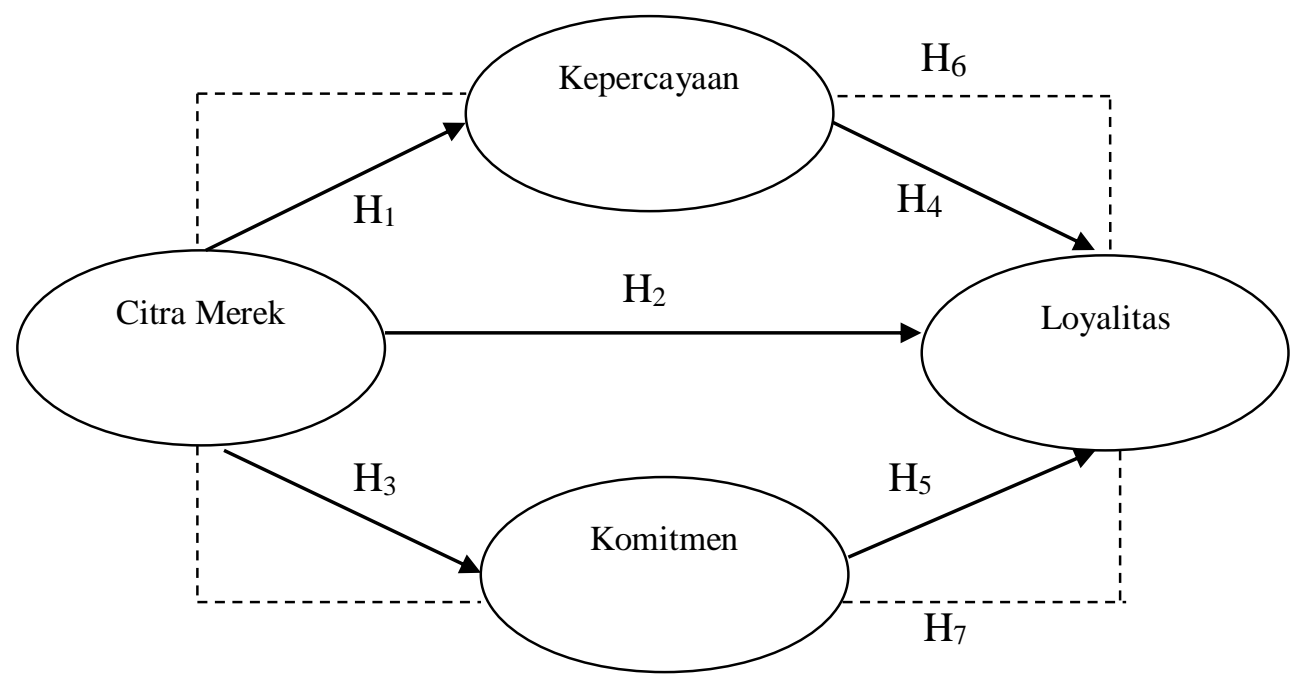

Gambar 1. Kerangka Konseptual Penelitian 


\section{METODE PENELITIAN}

Penelitian ini menggunakan metode kuantitatif dengan jenis penelitian explanatory research. Lokasi penelitian adalah Kota Malang. Skala pengukuran yang digunakan adalah Skala Likert. Populasi dalam penelitian ini adalah pelanggan yang memiliki akun pada aplikasi GOJEK serta melakukan transaksi online setidaknya lebih dari satu kali pada bulan Mei 2019 sampai Juli 2019. Karena jumlah populasi dalam penelitian ini tidak diketahui, maka untuk menentukan jumlah sampel yang akan diteliti, peneliti menggunakan rumus Wibisono sebanyak 96 responden. Teknik pengambilan sampel menggunakan incidental sampling dan purposive sampling.

Teknik pengumpulan data menggunakan data primer berupa kuesioner dan data sekunder berupa jurnal penelitian maupun media website GOJEK. Metode pengumpulan data menggunakan kuesioner secara online. Instrumen yang digunakan adalah melalui SPSS 25.0 dengan uji reliabilitas, uji validitas dan uji normalitas data. Sedangkan untuk teknik analisis data menggunakan analisis deskriptif dan analisis jalur.

\section{HASIL ANALISIS DATA \\ 1. Variabel Citra Merek}

Diketahui mean jawaban responden pada variabel citra merek (X1) sebesar 4,08 dan masuk dalam kategori sangat setuju. Rata-rata tertinggi terdapat pada item produk yang bermanfaat sebesar 4,16. Rata-rata ini masuk dalam kategori baik. Sedangkan rata-rata terendah terdapat pada item pertanyaan no. 5 yaitu sebesar 3,97 dan masuk dalam kategori baik.

Hal ini menunjukkan mayoritas konsumen setuju dengan GOJEK merupakan layanan aplikasi transportasi online yang bermanfaat walaupun masih ada 15,6 persen konsumen ragu-ragu terhadap manfaat aplikasi GOJEK, oleh karena itu GOJEK diharapkan selalu mempertahankan pelayanannya yang bermanfaat bagi pelanggannya.

\section{Variabel Kepercayaan}

Diketahui mean jawaban responden pada variabel kepercayaan $\left(Y_{1}\right)$ sebesar 4,07 dan masuk dalam kategori baik. Rata-rata tertinggi terdapat pada item pertanyaan no. 1 yaitu sebesar 4,14. Rata-rata ini masuk dalam kategori sangat setuju. Sedangkan rata-rata terendah terdapat pada item pertanyaan no. 3 yaitu sebesar 3,96 dan masuk dalam kategori baik.

Hal ini menunjukkan mayoritas konsumen setuju dengan GOJEK merupakan layanan aplikasi transportasi online yang aman bagi pelanggan walaupun masih ada 15,6 persen konsumen ragu-ragu terhadap keamanan aplikasi GOJEK, oleh karena itu GOJEK diharapkan selalu mengedepankan keamanan bagi pelanggannya.

\section{Variabel Komitmen}

Diketahui mean jawaban responden pada variabel komitmen $\left(\mathrm{Y}_{2}\right)$ sebesar 4,08 dan masuk dalam kategori baik. Rata-rata tertinggi terdapat pada item pertanyaan no. 2 yaitu sebesar 4,13 . Rata-rata ini masuk dalam 
kategori sangat setuju. Sedangkan rata-rata terendah terdapat pada item pertanyaan no. 4 yaitu sebesar 3,97 dan masuk dalam kategori baik.

Hal ini menunjukkan mayoritas konsumen setuju dengan GOJEK merupakan layanan aplikasi transportasi online yang menawarkan produk yang dipersonalisasi untuk memenuhi kebutuhan pelanggan walaupun masih ada 11,5 persen konsumen ragu-ragu terhadap manfaat aplikasi GOJEK, oleh karena itu GOJEK diharapkan selalu memberikan informasi mengenai pelayanannya terutama pada para pelanggan barunya.

\section{Variabel Loyalitas}

Diketahui mean jawaban responden pada variabel loyalitas $(Z)$ sebesar 4,07 dan masuk dalam kategori baik. Rata-rata tertinggi terdapat pada item pertanyaan no. 3 yaitu sebesar 4,15 . Rata-rata ini masuk dalam kategori baik. Sedangkan rata-rata terendah terdapat pada item pertanyaan no. 2 yaitu sebesar 3,96 dan masuk dalam kategori setuju.

Hal ini menunjukkan mayoritas konsumen setuju menetapkan GOJEK sebagai pilihan pertama dalam layanan transportasi online walaupun masih ada 10,4 persen konsumen ragu-ragu untuk memilih GOJEK sebagai pilihan pertama, oleh karena itu GOJEK diharapkan selalu mengembangkan layanan terbaiknya agar selalu mempunyai kompetensi tinggi.

\section{Hasil Analisis Jalur}

Tabel 1. Hasil Analisis Jalur (Pengaruh Langsung)

\begin{tabular}{|c|l|l|l|}
\hline MODEL & \multicolumn{1}{|c|}{ VARIABEL } & \multicolumn{1}{|c|}{$\begin{array}{c}\text { BESAR } \\
\text { PENGARUH }\end{array}$} & PERSAMAAN \\
\hline 1 & $\begin{array}{l}\text { Citra Merek }(\mathrm{X}) \text { terhadap } \\
\text { Kepercayaan }\left(\mathrm{Y}_{1}\right)\end{array}$ & 0,906 & $\mathrm{Y}_{1}=0,906 \mathrm{X}$ \\
\hline 2 & $\begin{array}{l}\text { Citra Merek }(\mathrm{X}) \text { terhadap } \\
\text { Loyalitas }(\mathrm{Z})\end{array}$ & 0,925 & $\mathrm{Z}=0,925 \mathrm{X}$ \\
\hline 3 & $\begin{array}{l}\text { Citra Merek }(\mathrm{X}) \text { terhadap } \\
\text { Komitmen }\left(\mathrm{Y}_{2}\right)\end{array}$ & 0,960 & $\mathrm{Y}_{2}=0,960 \mathrm{X}$ \\
\hline 4 & $\begin{array}{l}\text { Kepercayaan }\left(\mathrm{Y}_{1}\right) \text { terhadap } \\
\text { Loyalitas }(\mathrm{Z})\end{array}$ & 0,763 & $\mathrm{Z}=0,763 \mathrm{Y}_{1}$ \\
\hline 5 & $\begin{array}{l}\text { Komitmen }\left(\mathrm{Y}_{2}\right) \text { terhadap } \\
\text { Loyalitas }(\mathrm{Z})\end{array}$ & 0,200 & $\mathrm{Z}=0,200 \mathrm{Y}_{2}$ \\
\hline
\end{tabular}

Sumber: data primer diolah, 2019

\section{PEMBAHASAN}

$H_{1}$ : citra merek $(X)$ berpengaruh langsung terhadap kepercayaan $\left(Y_{1}\right)$

Hasil pengujian data diperoleh bahwa signifikansi $(0,000)$ lebih kecil dari alpha $5 \%(0,05)$ maka dapat diimplikasikan terdapat pengaruh positif dan signifikan citra merek terhadap kepercayaan. Semakin baik citra merek yang dibangun oleh GOJEK maka kepercayaan pelanggan akan semakin meningkat atau sebaliknya semakin tidak baik citra merek maka kepercayaan pelanggan akan semakin menurun. 
Hasil penelitian ini didukung oleh penelitian serupa yang dilakukan oleh Prasetya, Kumadji, dan Yulianto (2014) yang menyatakan bahwa terdapat pengaruh langsung dan signifikan variabel citra merek terhadap variabel kepercayaan. Akan tetapi hasil penelitian ini tidak sejalan dengan penelitian Maliyah (2015) yang menyatakan bahwa tidak terdapat pengaruh antara variabel citra merek terhadap kepercayaan.

Citra merek merupakan representasi dari keseluruhan persepsi terhadap merek dan dibentuk dari informasi dan pengalaman masa lalu terhadap merek tersebut. Dalam hal ini adalah GOJEK. Citra yang positif akan membuat merek lebih mudah diingat oleh pelanggan. Surachman (2008) menyatakan bahwa citra merek merupakan bagian dari citra yang dapat dikenali namun tidak dapat diucapkan, seperti lambang, desain huruf atau warna khusus, atau persepsi pelanggan atas sebuah produk jasa yang diwakili oleh suatu merek.

Citra merek meliputi pengetahuan dan kepercayaan akan atribut merek, konsekuensi dari penggunaan merek tersebut, dan situasi penggunaan yang sesuai, begitu juga dengan evaluasi, perasaan, dan emosi yang diasosiasikan dengan merek tersebut. Citra merek didefinisikan sebagai persepsi konsumen dan preferensi terhadap merek, sebagaimana yang direfleksikan oleh berbagai macam asosiasi merek yang ada dalam ingatan konsumen. Meskipun asosiasi merek dapat terjadi dalam berbagai macam bentuk tapi dapat dibedakan menjadi asosiasi performansi dan asosiasi imajeri yang berhubungan dengan atribut dan kelebihan merek. Hal ini dapat diimplikasikan bahwa citra merek merupakan serangkaian kepercayaan konsumen tentang merek tertentu sehingga asosiasi merek tersebut melekat di benak konsumen.

Terdapat beberapa hal yang dilakukan oleh GOJEK dalam rangka meningatkan tingkat kepercayaan pelanggan melalui citra merek yaitu adalah memastikan keamanan di setiap pemakaian layanannya. GOJEK mengeluarkan fitur keamanan yang inovatif berupa "Tombol Darurat" dan "Bagikan Perjalanan". Selain itu GOJEK juga memberikan Asuransi di setiap pelayanannya untuk menjamin perlindungan keselamatan dan kecelakaan yang akan membuat tingkat kepercayaan pelanggan dalam penggunaan layanan GOJEK akan semakin tinggi.

\section{$\mathrm{H}_{2}$ : citra merek $(X)$ berpengaruh langsung terhadap loyalitas $(Z)$}

Berdasarkan hasil analisis data diperoleh kesimpulan bahwa citra merek berpengaruh langsung pada loyalitas. Hasil pengujian langsung Citra Merek terhadap Loyalitas diperoleh signifikansi $(0,000)$ lebih kecil dari alpha $5 \%(0,050)$ maka diimplikasikan terdapat pengaruh positif dan signifikan Citra Merek terhadap Loyalitas. Semakin baik citra merek yang dibangun oleh GOJEK maka loyalitas pelanggan akan semakin meningkat atau sebaliknya semakin tidak baik citra merek maka loyalitas pelanggan akan semakin menurun.

Hasil penelitian ini didukung oleh penelitian Efendy dan Suryadinata (2015) yang menyatakan bahwa terdapat pengaruh antara variabel citra merek terhadap loyalitas. Namun ditolak oleh hasil penelitian Noor (2014) yang menyatakan citra merek tidak berpengaruh signifikan terhadap loyalitas. 
Menurut Rangkuti dalam Wijiyanto dan Iriani (2013) citra merek adalah sekumpulan asosiasi merek yang terbentuk dibenak konsumen yang terbiasa menggunakan merek tertentu cenderung memiliki konsistensi terhadap brand imageatau hal ini disebut juga dengan kepribadian merek. Persepsi positif yang diciptakan perusahaan dalam suatu produknya merupakan gambaran citra merek yang baik dalam benak konsumen. Menurut Kotler dalam Ayu, et al 2013) perusahaan dalam hal ini adalah pemasar, harus dapat menempatkan merek dengan jelas dalam pikiran konsumen, salah satunya dengan membentuk citra merek yang kuat. Citra merek yang kuat membuat pesan merek tertentu unggul atas merek pesaing. Hal ini membuat perilaku pelanggan akan terpengaruh dan ditentukan oleh citra merek.

Pengaruh brand image terhadap loyalitas konsumen terletak pada keinginan-keinginan dan pilihan konsumen atas suatu merek adalah merupakan sikap konsumen. Dalam banyak hal, sikap terhadap merek tertentu sering mengetahui apakah konsumen akan loyal atau tidak. Jadi dapat dikatakan brand yang baik dari suatu merek dapat mengarahkan pada loyalitas konsumen terhadap suatu merek. Penting bagi perusahaan untuk membangun brand dari image yang dihasilakannya, agar brand image yang dibangun dapat dipersepsikan dengan baik oleh konsumen. Bagaimanapun juga brand image yang baik ikut membantu terwujudnya loyalitas, sehingga merek tersebut dapat berkembang jadi merek yang kuat di pasaran. Dengan kata lain, merek mencerminkan keseluruhan persepsi dan perasaan konsumen mengenai atribut dan kinerja produk, nama merek dan maknanya, dan perusahaan yang diasosiasikan dengan merek bersangkutan.

Loyalitas dapat diartikan sebagai kesetiaan pelangan terhadap GOJEK. Pelanggan yang memiliki loyalitas tinggi akan menggunakan jasa dari GOJEK dalam setiap aktivitasnya yang berhubungan dengan pemakaian jasa transportasi online. Loyalitas harus dipertahankan dengan baik oleh perusahaan karena secara tidak langsung dengan banyaknya pelanggan GOJEK, maka pertumbuhan perusahaan akan semakin bagus, omzet yang didapatkan juga akan bertambah.

Terdapat beberapa hal yang dilakukan oleh GOJEK dalam rangka meningatkan tingkat loyalitas pelanggan melalui citra merek yaitu adalah sering memberitahukan pengetahuan dalam melakukan kegiatan sosial yang dilakukan GOJEK maupun komunitas GOJEK dalam iklan maupun acara-acara yang diselenggarakan oleh perusahaan. Hal ini mampu menarik minat konsumen untuk melakukan pemakaian ulang layanan GOJEK yang memjadikan salah satu pembentuk loyalitas dari pelanggan GOJEK.

GOJEK juga menerapkan sistem token di setiap transaksi elektroniknya (GO-Pay) yang bisa dikonversikan menjadi berupa GO-Poin. Dengan kemasannya berupa fitur Gamifaction yang unik dan masih tergolong baru di Indonesia akan mampu meningkatkan tingkat loyalitas pelanggan GOJEK. 


\section{$\mathrm{H}_{3}$ : citra merek $(X)$ berpengaruh langsung terhadap komitmen $\left(Y_{2}\right)$}

Berdasarkan hasil analisis data diperoleh kesimpulan bahwa citra merek berpengaruh langsung pada komitmen. Hasil pengujian langsung diperoleh signifikansi $(0,000)$ lebih kecil dari alpha $5 \%(0,050)$ maka diimplikasikan terdapat pengaruh positif dan signifikan citra merek terhadap komitmen. Semakin baik citra merek yang dibangun oleh GOJEK maka komitmen pelanggan akan semakin meningkat atau sebaliknya semakin tidak baik citra merek maka komitmen pelanggan akan semakin menurun.

Hasil penelitian ini sejalan dengan penelitian Ogba dan Tan (2009) yang menyatakan bahwa citra merek dapat mempengaruhi komitmen pelanggan. Akan tetapi hasil penelitian ini tidak sejalan dengan penelitian Maliyah (2015) yang menyatakan bahwa tidak terdapat pengaruh antara variabel citra merek terhadap variabel komitmen.

Menurut Surachman (2008), citra merek merupakan bagian dari citra yang dapat dikenali namun tidak dapat diucapkan, seperti lambang, desain huruf atau warna khusus, atau persepsi pelanggan atas sebuah produk jasa yang diwakili oleh suatu merek.

Seiring berkembangnya GOJEK dari tahun ke tahun. GOJEK sudah mengalami beberapa perubahan, baik itu penambahan layanan, peubahan harga, maupun tampilan aplikasi. Perubahan-perubahan tersebut tidak akan membuat GOJEK kehilangan konsumennya jika pelanggan tersebut memiliki rasa komitmen terhadap pemakaian GOJEK sebagai pilihan jasa transportasi online.

\section{$\mathrm{H}_{4}$ : kepercayaan $\left(\mathrm{Y}_{1}\right)$ berpengaruh langsung terhadap loyalitas $(\mathrm{Z})$}

Berdasarkan hasil analisis data diperoleh kesimpulan kepercayaan berpengaruh langsung pada loyalitas. Hasil pengujian langsung diperoleh signifikansi $(0,000)$ lebih kecil dari alpha $5 \%(0,050)$ maka diimplikasikan terdapat pengaruh positif dan signifikan kepercayaan terhadap loyalitas.

Hasil penelitian ini didukung oleh penelitian serupa yang dilakukan oleh Kurniawan (2018) menunjukkan bahwa variabel kepercayaan berpengaruh positif terhadap loyalitas konsumen. Akan tetapi hasil penelitian ini tidak sejalan dengan penelitian Maliyah (2015) yang menyatakan bahwa tidak terdapat pengaruh antara variabel kepercayaan terhadap loyalitas.

Menurut Agustin dan Singh (2005), kepercayaan mengurangi ketidakpastian dalam lingkungan di mana konsumen merasa sangat rentan karena mereka tahu mereka bisa mengandalkan merek terpercaya. Ketika sebuah merek memiliki kemampuan untuk terus memenuhi minat dan harapan terbaik pelanggan, maka pelanggan cenderung mempercayai merek. Contohnya, pelanggan akan menyimpulkan jika suatu merek fungsionalnya terpercaya, jika kualitas adalah kredibel atau keamanan merek sebelum mereka mempertimbangkan untuk percaya merek tersebut (Bart, et al., 2005). Dengan demikian, kepercayaan merek adalah hasil dari proses merasakan dan berpikir dengan baik tentang suatu merek dan dapat dilihat sebagai pengaruh reliabilitas dan kredibilitas (Chaudhuri dan Holbrook, 2001). Kembali lagi, mungkin memperkuat perilaku pembelian berulang oleh konsumen dan akhirnya menyebabkan sikap dan perilaku merek atau loyalitas pembelian di masa depan (Delgado et al., 2003). 
Akibatnya, sebuah merek dapat dipercaya adalah yang konsisten menjaga nilai mereknya kepada pelanggan melalui kinerja yang unggul, maka jaminan loyalitas pelanggan akan sebuah merek telah dalam proses (Chiou dan Droge, 2006). Oleh karena itu, dapat dikatakan bahwa semakin tinggi tingkat kepercayaan merek pada pelanggan, semakin tinggi pula harapan loyalitas merek pada pelanggan. Bukti empiris sebelumnya menemukan hubungan positif antara kepercayaan merek dan loyalitas merek (Morgan dan Hunt, 1994; Doney dan Cannon, 1997; Chiou dan Droge, 2006) dan kepercayaan merek bisa diharapkan menciptakan loyalitas merek pada perusahaan.

Lau dan Lee (1999) menyatakan bahwa kepercayaan terhadap suatu merek akan menimbulkan loyalitas merek, pengalaman positif yang dirasakan pelanggan terhadap merek tersebut akan mendorong pelanggan untuk mulai mempercayai suatu merek lalu berkembang menjadi setia dan loyal terhadap merek tersebut. Hal ini menunjukkan adanya pengaruh kepercayaan terhadap loyalitas merek.

Apabila kepercayaan yang tinggi masyarakat pada layanan GOJEK dapat meningkatkan retensi pelanggan maka dengan mudah loyalitas konsumen dapat terbentuk. Loyalitas pelanggan tidak dapat dibentuk hanya karena produk tersebut diterima baik oleh konsumen, tetapi pembuktian secara terus menerus (konsistensi) pada kualitas layanan menjadi faktor penentu loyalitas. Tidak mudah untuk mencapai konsumen yang loyal pada produk maupun perusahaan, peningkatan secara berkelanjutan, mewujudkan kepuasan konsumen juga menjadi faktor pembentuknya.

GOJEK yang sudah berdiri sejak tahun 2010 memaksimalkan layanannya dengan memberikan nilai (rating) dari setiap pelanggan yang telah memakai layanan GOJEK. Dimana rating yang baik akan membuktikan bahwa layanan GOJEK memang kompatibel untuk digunakan masyarakat. Hal tersebut akan mempengaruhi rasa kepercayaan pelanggan terhadap GOJEK jika suatu saat pelanggan tersebut akan memakai ulang layanan.

Jadi dapat diimplikasikan bahwa kepercayaan pelanggan GOJEK akan mempunyai hubungan yang positif dengan niat ulang maupun loyalitas. Kepercayaan pelanggan mempunyai pengaruh terhadap loyalitas berupa niat ulang melakukan pembelian, dan melakukan intensitas pemakaian ulang layanan GOJEK.

\section{$\mathrm{H}_{5}$ : komitmen $\left(\mathrm{Y}_{2}\right)$ berpengaruh langsung terhadap loyalitas $(\mathrm{Z})$}

Berdasarkan hasil analisis data diperoleh kesimpulan komitmen berpengaruh langsung pada loyalitas. Hasil pengujian langsung diperoleh signifikansi $(0,002)$ lebih kecil dari alpha $5 \%(0,050)$ maka diimplikasikan terdapat pengaruh positif dan signifikan komitmen terhadap loyalitas.

Hasil penelitian ini didukung oleh penelitian serupa yang dilakukan oleh Maliyah (2015) menunjukkan bahwa variabel komitmen berpengaruh positif terhadap loyalitas.

Komitmen merupakan keinginan yang kuat yang bersifat terus menerus untuk selalu menjaga hubungan baik dengan perusahaan. (Fullerton, 2003; Lacey, 2007) dalam Suratman (2015:3). Menurut penelitian Suratman (2015:11) yang berjudul "Analisi Loyalitas Konsumen 
yang dipengaruhi Kepuasan, Kepercayaan dan Komitmen Studi pada Pelanggan Transportasi Rosalia Indah, Karanganyar" menyatakan bahwa adanya pengaruh positif antara komitmen pada loyalitas.

Komitmen adalah sikap atau tindakan konsumen dalam memilih suatu produk secara terus menerus (Widyawati, 2008:89). Definisi lain komitmen adalah suatu keinginan kuat untuk memelihara suatu hubungan yang dihargai (Utami dan Hanum, 2010:402). Komitmen terjadi dimana pihak yang memberikan komitmen menganggap suatu hubungan adalah penting yang dapat diukur melalui keinginan mempertahankan hubungan, kemauan memelihara hubungan dan keyakinan akan kestabilan hubungan. Komitmen tidak akan terjadi kalau salah satu atau kedua belah pihak merasa bahwa hubungannya tidak menguntungkan.

Dengan perkataan lain komitmen berarti didalamnya terdapat suatu hubungan yang berharga yang perlu dipertahankan terus, dimana masingmasing pihak bersedia bekerja sama untuk mempertahankan hubunganini. Perilaku penggunaan jasa informasi hasil penelitian dipengaruhi secara langsung oleh komitmen pengguna (user) untuk tetap melakukan suatu keterhubungan, sehingga komitmen akan mempunyai konsekuensi terhadap loyalitas (Setiawan dan Ukudi, 2007:218).

GOJEK berusaha mempertahankan hubungannya dengan para pelanggannya melalui email pelanggan yang teraktivasi pada aplikasi. Dengan demikian semua yang berkaitan dengan penawaran produk, berita kegiatan-kegiatan GOJEK, maupun produk-produk terbaru yang diluncurkan akan langsung disampaikan kepada masyarakat. Hal ini dilakukan sebagai alat untuk memelihara hubungan dan keyakinan akan kestabilan hubungan GOJEK terhadap pelanggannya.

Tabel 2. Hasil Analisis Jalur (Pengaruh Tidak Langsung)

\begin{tabular}{|c|c|c|c|}
\hline MODEL & VARIABEL & $\begin{array}{l}\text { BESAR } \\
\text { PENGARUH }\end{array}$ & PERSAMAAN \\
\hline 6 & $\begin{array}{l}\text { Citra Merek }\left(\mathrm{X}_{1}\right) \text { terhadap } \\
\text { Loyalitas } \quad\left(\mathrm{Z}_{1}\right) \quad \text { dimediasi } \\
\text { Kepercayaan }\left(\mathrm{Y}_{1}\right)\end{array}$ & 0,691 & $\begin{array}{l}\beta_{1} \times \beta_{4}=0,906 \times \\
0,763 \\
=0,691\end{array}$ \\
\hline 7 & $\begin{array}{l}\text { Citra Merek }\left(X_{1}\right) \text { terhadap } \\
\text { Loyalitas }\left(Z_{1}\right) \quad \text { dimediasi } \\
\text { Komitmen }\left(Y_{2}\right)\end{array}$ & 0,192 & $\begin{array}{l}\mathrm{B}_{3} \times \beta_{5}=0,960 \times \\
0,200 \\
=0,192\end{array}$ \\
\hline
\end{tabular}

Sumber: data primer diolah, 2019

\section{$\mathrm{H}_{6}$ : citra merek $(\mathrm{X})$ berpengaruh tidak langsung terhadap loyalitas $(\mathrm{Z})$ melalui kepercayaan $\left(\mathrm{Y}_{1}\right)$.}

Hasil penelitian menunjukkan pengaruh Citra Merek $\left(X_{1}\right)$ terhadap Loyalitas $(Z)$ dimediasi Kepercayaan $\left(Y_{1}\right)$ sebesar 0,906 $\times 0,763=0.691$ (sig 0,00$)$ dengan kata lain terdapat pengaruh tidak langsung Pengaruh Citra Merek $\left(\mathrm{X}_{1}\right)$ terhadap Loyalitas $(\mathrm{Z})$ dimediasi Kepercayaan $\left(\mathrm{Y}_{1}\right)$ sebesar 0.691 (sig 0,00). Artinya kepercayaan pelanggan mampu memediasi pengaruh citra merek terhadap loyalitas dimana citra merek 
akan mempengaruhi loyalitas pelanggan apabila pelanggan percaya terhadap GOJEK.

Hasil penelitian ini tidak sejalan dengan penelitian Kurniawan (2016) yang menyatakan bahwa variabel kepercayaan tidak dapat memediasi pengaruh citra merek terhadap loyalitas.

Apabila suatu merek mampu memenuhi harapan konsumen atau bahkan melebihi harapan konsumen dan memberikan jaminan kualitas pada setiap kesempatan penggunaannya, serta merek tersebut diproduksi oleh perusahaan yang memiliki reputasi, maka konsumen akan semakin yakin dengan pilihannya dan konsumen akan memiliki kepercayaan pada merek, menyukai merek, serta menganggap merek tersebut sebagai bagian dari dirinya. Dengan demikian, kesetiaan merek akan lebih mudah untuk dibentuk dan perusahaan akan memiliki nama merek yang memiliki kesetiaan konsumen yang kuat karena kepercayaan merek (brand trust) akan menentukan kesetiaan konsumen terhadap merek dan kepercayaan akan berpotensi menciptakan hubungan-hubungan yang bernilai tinggi (Morgan dan Hunt, 1994 dalam Edris, 2009). Selain Citra merek memberikan nilai tersendiri terhadap persepsi konsumen yang akan meningkatkan kepercayaan akan produk itu sendiri, seperti pada aspek kualitas.

Dalam hal ini GOJEK sebagai penyedia layanan transportasi online yang dinilai masyarakat kompeten dalam pelayanannya dengan pelangganpelanggan setianya yang selalu memakai ulang layanan GOJEK. Pelanggan memakai ulang layanan GOJEK juga karena mereka memiliki kepercayaan yang membuat semakin yakin terhadap nilai layanan yang diberikan GOJEK.

\section{$\mathrm{H}_{7}$ : citra merek $(X)$ berpengaruh tidak langsung terhadap loyalitas $(Z)$ melalui komitmen $\left(\mathrm{Y}_{2}\right)$.}

Hasil penelitian menunjukkan pengaruh Citra Merek terhadap Loyalitas dimediasi Komitmen sebesar $0,960 \times 0,200=0.192$. Artinya komitmen dari perusahaan ke pelanggan mampu memediasi pengaruh citra merek terhadap loyalitas dimana citra merek akan mempengaruhi loyalitas pelanggan apabila GOJEK berkomitmen tinggi dalam pelayanannya terhadap pelanggan. Hasil pengujian tidak langsung dari Uji Sobel diperoleh signifikansi $(0,000)$ lebih kecil dari alpha $5 \%(0,05)$ maka diimplikasikan terdapat pengaruh positif dan signifikan citra merek terhadap loyalitas dimediasi komitmen artinya komitmen perusahaan terhadap pelanggan mampu memediasi citra merek terhadap loyalitas.

Hasil penelitian ini bertolak belakang dengan penelitian Bauer, Stokburger-Sauer, dan Exler (2008) yang menyatakan bahwa komitmen tidak dapat memediasi citra merek terhadap loyalitas.

Citra perusahaan dapat menjadi pengenal produk/jasa yang ditawarkan. citra perusahaan yang baik membantu meningkatkan penjualan perusahaan dan pangsa pasarnya dan untuk membangun dan menjaga hubungan dengan loyalitas (Tang, 2007). Disamping itu, citra perusahaan juga dapat digunakan untuk memperbaiki atau mempertahankan posisi persaingan, mempertahankan pelanggan lama, dan menjaring pelanggan baru. 
Morgan dan Hunt (1994) dalam Edris (2009), berpendapat bahwa kesetiaan merek akan lebih mudah untuk dibentuk dan perusahaan akan memiliki nama merek yang memiliki kesetiaan konsumen yang kuat karena kepercayaan merek (brand trust) akan menentukan kesetiaan konsumen terhadap merek akan berpotensi menciptakan hubungan-hubungan yang bernilai tinggi.

Pemberitahuan layanan kepada pelanggan merupakan bentuk GOJEK dalam mempertahankan hubungan dengan para pelanggannya agar informasi-informasi mengenai GOJEK diterima dengan baik oleh masyarakat. Dalam hal ini pelanggan akan memakai ulang layanan dari GOJEK karena mereka sadar akan hubungan yang baik dengan perusahaan. Maka diharapkan di antara GOJEK dengan pelanggan selalu mempertahankan hubungan yang baik.

\section{SIMPULAN DAN SARAN}

Pada penelitian yang dilakukan, peneliti bermaksud untuk mengetahui pengaruh citra merek terhadap kepercayaan, pengaruh citra merek terhadap loyalitas, pengaruh citra merek terhadap komitmen, pengaruh kepercayaan dan komitmen terhadap loyalitas, pengaruh citra merek terhadap loyalitas dimediasi kepercayaan dan pengaruh citra merek terhadap loyalitas dimediasi komitmen. Responden dalam penelitian ini adalah pelanggan GOJEK di Kota Malang. Berdasarkan hasil pengujian data yang diperoleh pada masing-masing variabel didapatkan hasil sebagai berikut:

1) Citra merek berpengaruh positif dan signifikan terhadap kepercayaan GOJEK. Dapat diartikan bahwa semakin baik citra merek yang dilakukan oleh GOJEK, maka semakin meningkat pula kepercayaan pelanggan GOJEK di Kota Malang.

2) Citra merek berpengaruh positif dan signifikan terhadap loyalitas pelanggan GOJEK. Dapat diartikan bahwa semakin baik citra merek yang dilakukan oleh GOJEK, maka loyalitas pelanggan GOJEK di Kota Malang akan semakin meningkat.

3) Citra merek berpengaruh positif dan signifikan terhadap komitmen pelanggan GOJEK. Dapat diartikan bahwa semakin baik citra merek yang dilakukan oleh GOJEK, maka komitmen pelanggan GOJEK di Kota Malang akan semakin meningkat.

4) Kepercayaan berpengaruh positif dan signifikan terhadap loyalitas pelanggan GOJEK. Dapat diartikan bahwa semakin baik kepercayaan dan komitmen yang didapatkan oleh GOJEK, maka loyalitas pelanggan GOJEK di Kota Malang akan semakin meningkat.

5) Komitmen berpengaruh positif dan signifikan terhadap loyalitas pelanggan GOJEK. Dapat diartikan bahwa semakin baik kepercayaan dan komitmen yang didapatkan oleh GOJEK, maka loyalitas akan semakin meningkat.

6) Terdapat pengaruh tidak langsung Citra Merek terhadap Loyalitas melalui Kepercayaan pelanggan GOJEK.

7) Terdapat pengaruh tidak langsung Citra Merek terhadap Loyalitas melalui Komitmen pelanggan GOJEK. 
Pada proses pembuatan hasil penelitian ini, peneliti mengajukan beberapa saran yang dapat dipertimbangkan bagi GOJEK dan peneliti selanjutnya sebagai berikut:

1) Bagi GOJEK

Berdasarkan hasil penelitian yang dilakukan oleh peneliti, Citra Merek berpengaruh terhadap kepercayaan, loyalitas dan komitmen pelanggan, oleh karena itu citra merek harus diciptakan dengan baik agar tingkat kepercayaan, loyalitas dan komitmen pelanggan tetap terjaga dengan baik. Jika loyalitas dipertahankan, maka tidak akan kehilangan pelanggan dan dalam jangka waktu depan dapat meningkatkan pendapatan perusahaan. Perusahaan harus tetap mengembangkan pelayanan aplikasinya lebih baik lagi agar pelanggan tetap mempercayakan GOJEK sebagai aplikasi yang tidak mengecewakan pelanggannya.

2) Bagi Peneliti selanjutnya

Penelitian yang dilakan oleh peneliti memiliki keterbatasan dalam jumlah variabel yang digunakan. Diharapkan pada penelitian selanjutnya dapat menambah jumlah variabel seperti variabel pelayanan sehingga hasil yang diperoleh lebih maksimal.

\section{DAFTAR PUSTAKA}

Arikunto, Suharsimi, 2002. Prosedur Penelitian Suatu Pendekatan Praktik. Edisi Revisi. Jakarta : Rineka Cipta

Cahya, Putriana. 2018. Makin Ketat, Begini Persaingan Tiga Transportasi Online Terbesar di Indoneisia (online). https://www.idntimes.com/business/economy/putrianacahya/persaingan-tiga-transportasi-online-terbesar/full (diakses 17 Juni 2019)

Colquitt, J.A. Lepine, J.A dan Wesson, M.J. 2009. Organizational behavior: Improving Performance and Commitment in the Workplace. McGaw-Hill.

Dagger, Tracey S. dan O'Brien, Timothy K. 2010. Differences in relationship benefits, satisfaction, trust, commitment and loyalty for novice and experienced service users. European Journal of Marketing. Vol.44 No.9, pp. 1535.

Darmawan, Deni. 2014. Metode Penelitian Kuantitatif, Cetakan 2. Bandung: PT. Remaja Rosdakarya

Darwin, Steven dan Sondang, Kunto. 2014. Analisis Pengaruh Kualitas Layanan terhadap Loyalitas Pelanggan dengan Kepuasan dan Kepercayaan Pelanggan sebagai Variabel Intervening pada Asuransi Jiwa Manulife Indonesia. Surabaya; Jurnal Manajemen Pemasaran Petra Vol. 2 No. 1.

Edison, Emron, Anwar, Yohny, dan Komaryah, Imas. 2016. Manajemen Sumber Daya Manusia. Bandung; Alfabeta.

Ellena, Freida. 2011. Analisis Pengaruh Kepercayaan, Komitmen, Komunikasi, dan Penanganan Keluhan terhadap Loyalitas Nasabah.

Ghozali, Imam. 2006. Aplikasi Analisis Multivariate dengan Program SPSS (Edisi Ke 4). Semarang; Badan Penerbit Universitas Diponegoro. 
Herman. 2015. Ini Daftar Pemenang "Indonesia Golden Ring Awards 2015" (online). $\quad$ https://www.beritasatu.com/iptek/322468/ini-daftarpemenang-indonesia-golden-ring-awards-2015 (diakses 17 Juni 2019)

Jasfar, Farida. 2005. Manajemen Jasa Pendekatan Terpadu. Bogor; Ghalia Indonesia.

Lovelock, Christopher dan Wright, Lauren K. 2007. Manajemen Pemasaran Jasa. Alih bahasa Agus Widyantor, Cetakan Kedua, Jakarta; PT INDEKS.

Kotler, Philip and Gary Amstrong. 2008. Prinsip-prinsip Pemasaran. Edisi 12. Jilid 1. Jakarta: Erlangga.

Kotler, Philip dan Keller, Kevin Lane. 2009. Manajemen Pemasaran. jilid 1 Edisi 13. Jakarta : Erlangga.

Kotler, Philip dan Keller Kevin Lane. 2013. Manajemen Pemasaran, edisi kedua belas Jilid 1. Terjemahan Benyamin Molan. Indonesia: PT. Macana Jaya Cemerlang.

Lau, G. T. dan Lee, S. H. 1999. Consumer's Trust in Brand and The Link to Brand Loyality. Jurnal of market focused management, Vol.4 No.4.

Lamb, Charles. 2001. Pemasaran: Edisi Pertama. Jakarta; Salemba Empat.

Leverin, A dan Liljander, V. 2006. Does relationship marketing improve customer relationship satisfaction and loyality?. International Journal od Bank Marketing.

Lovelock, Christopher dan Wright, Lauren K. 2007. Manajemen Pemasaran Jasa. Alih bahasa Agus Widyantor, Cetakan Kedua, Jakarta; PT INDEKS.

Lovelock, Christopher, et.al. 2010. Pemasaran Jasa. Edisi 7, Jilid 2. Erlangga: Jakarta.

Malhotra, N. 2009. Riset Pemasaran edisi keempat. Jakarta: Penerbit Indeks

Maliyah, Siti. 2015. Pengaruh citra merek, kepercayaan (trust) dan komitmen terhadap loyalitas nasabah pada PT Henan Putihrai Asset Management, Jurnal IImiah Manajemen dan Bisnis, Vol. 1 No. 1.

Morgan, R.M dan Hunt, S.D. 1994. The commitment-trust theory of relationship marketing. Journal of Marketing, Vol. 58 No. 3.

Mustafa, Zainal. 2009. Mengurai Variabel Hingga Instrumentasi. Yogyakarta: Graha IImu

Ndubisi, Nelson O. 2007. Relationship Marketing and Customer Loyalty. Marketing Intelligence and Planning Vol 25 No 1.

Peppers, Don dan Rogers, Marta. 2004. Managing Customer Relationship. Canada; willey.

Ramadania. 2002. Kepercayaan dan Komitmen sebagai Perantara Kunci Relationship Marketing dalam Membangun Loyalitas (Survey pada Nasabah Bank Muamalat Indonesia. Surabaya; Jurnal Riset Ekonomi dan Manajemen 2.

Rangkuti, Freddy. 2002. The Power of Brands. Jakarta; PT Gramedia Pustaka Utama.

Rizal, Asnan Furinto. 2009. Marketing reloaded: kompilasi konsep dan praktik pemasaran. Jakarta; Salemba Empat. 
Robbins, Stephen P. 2001. Perilaku Organisasi: Konsep, Kontroversi, Aplikasi,, Jilid 1. Jakarta; Prenhallindo.

Sahnaz dan Susan. 2016. Strategi Kualitas Hubungan Merek, Komitmen, Kecintaan terhadap Loyalitas Merek pada Restoran Waralaba, jurnal ilmiah manajemen Universitas Mercu Buana Jakarta Vol. 6 No. 3.

Sangadji, Etta Mamang dan Sopiah. 2013. Perilaku Konsumen. CV Andi Offset.

Sanusi, Anwar. 2014. Metodelogi Penelitian Bisnis. Jakarta: Salemba Empat

Sarjono, Harjadi \& Julianita, Winda. 2005. SPSS vs LISREL, sebuah pengantar, aplikasi untuk riset. Jakarta: Salemba Empat

Sheth, Jagdish, dan Mittal, Banwari. 2004. Consumer Behavior: $A$ Manajerial Perspective, edisi kedua. Singapore: Thomson.

Singarimbun, Masri \& Sofian Effendi. 2008. Metode Penelitian Survai. Jakarta: LP3ES.

Siregar, S. 2014. Metode Penelitian Kuantitatif SPSS. Jakarta: Kencana

Sugiyono, 2017. Metode Penelitian Kualitatif, Kuantitatif, dan $R$ \& $D$. Bandung: Alvabeta

Sumarwan, Ujang. 2011. Perilaku Konsumen Teori dan Penerapannya dalam Pemasaran. Edisi kedua. Bogor: Penerbit Ghalia Indonesia.

Sujarweni, Wiratna. 2014. SPSS Untuk Penelitian. Yogyakarta: Pustaka Baru Press

Sundjoto dan Hadi, Agus Sofan. 2012. Pengaruh citra merek dan kesadaran merek terhadap ekuitas merek susu cair dalamkemasan "frisian flag" jurnal media mahardika, Vol. 11 No. 1.

Surachman. 2008. Dasar-Dasar Manajemen Merek (Alat Pemasaran untuk Memenangkan Persaingan). Malang; Bayumedia Publishing.

Susanti dan Wardana. 2015. Pengaruh kualitas produk dan citra merek terhadap kepuasan dan loyalitas pelanggan pada produk kosmetik hijau merek The Body Shop, E-Jurnal Manajemen Universitas Udayana, Vol. 4 No. 2.

Sutisna dan Pawitra. 2001. Perilaku Konsumen dan Komunikasi Pemasaran. Bandung; PT Remaja Rosdakarya.

Tjiptono, Fandy. 2009. Strategi Pemasaran. Edisi 2. Yogyakarta; Andi Offset.

Valenta, Elisa. 2019. Bom Waktu Lonjakan Tarif Ojek Online (online). https://beritagar.id/artikel/laporan-khas/bom-waktu-lonjakan-tarifojek-online (diakses 17 Juni 2019)

Wahyudi, Arif. 2018. Riset INRIX, Malang Jadi Kota Termacet Ketiga di Indonesia (online). https://halomalang.com/read/2018/02/riset-inrixmalang-jadi-kota-termacet-kedua-di-indonesia? (diakses 17 Juni 2019)

Yunita. 2011. Kepercayaan, Komitmen, Komunikasi, Penanganan Konflik, dan Perannya terhadap Kepuasan terhadap Loyalitas Nasabah Bank BCA di Surabaya, Journal of Business and Banking, Vol. 1 No. 1 